\title{
Effect of smoking on the genetic makeup of toll-like receptors 2 and 6
}

This article was published in the following Dove Press journal:

OncoTargets and Therapy

21 November 2016

Number of times this article has been viewed

\author{
Muhammad Kohailan' \\ Mohammad Alanazi' \\ Mahmoud Rouabhia ${ }^{2}$ \\ Abdullah Alamri' \\ Narasimha Reddy Parine' \\ Abdullah Alhadheq' \\ Santhosh Basavarajappa ${ }^{3}$ \\ Abdul Aziz Abdullah \\ Al-Kheraif ${ }^{3}$ \\ Abdelhabib Semlali' \\ 'Genome Research Chair, Department \\ of Biochemistry, College of Science, \\ King Saud University, Riyadh, Kingdom \\ of Saudi Arabia; ${ }^{2}$ Département de \\ Stomatologie, Faculté de Médecine \\ Dentaire, Groupe de Recherche \\ en Écologie Buccale, Université \\ Laval, Québec City, QC, Canada; \\ ${ }^{3}$ Dental Biomaterial Research Chair, \\ Department of Dental Health, College \\ of Applied Medical Sciences, King \\ Saud University, Riyadh, Kingdom of \\ Saudi Arabia
}

Background: Cigarette smoking is a major risk factor for lung cancer, asthma, and oral cancer, and is central to the altered innate immune responsiveness to infection. Many hypotheses have provided evidence that cigarette smoking induces more genetic changes in genes involved in the development of many cigarette-related diseases. This alteration may be from single-nucleotide polymorphisms (SNPs) in innate immunity genes, especially the toll-like receptors (TLRs).

Objective: In this study, the genotype frequencies of TLR2 and TLR6 in smoking and nonsmoking population were examined.

Methods: Saliva samples were collected from 177 smokers and 126 nonsmokers. The SNPs used were rs3804100 (1350 T/C, Ser450Ser) and rs3804099 (597 T/C, Asn199Asn) for TLR2 and rs3796508 (979 G/A, Val327Met) and rs5743810 (745 T/C, Ser249Pro) for TLR6.

Results: Results showed that TLR2 rs3804100 has a significant effect in short-term smokers $(\mathrm{OR}=2.63 ; P=0.04)$, and this effect is not observed in long-term smokers ( $>5$ years of smoking). Therefore, this early mutation may be repaired by the DNA repair system. For TLR2 rs3804099, the variation in genotype frequencies between the smokers and control patients was due to a late mutation, and its protective role appears only in long-term smokers ( $\mathrm{OR}=0.40, P=0.018$ ). In TLR6 rs5743810, the TT genotype is significantly higher in smokers than in nonsmokers $(\mathrm{OR}=6.90)$. The effect of this SNP is observed in long-term smokers, regardless of the smoking regime per day.

Conclusion: TLR2 (rs3804100 and rs3804099) and TLR6 (rs5743810) can be used as a potential index in the diagnosis and prevention of more diseases caused by smoking.

Keywords: polymorphism, toll-like receptor, genotyping, smoking, TLR2, TLR6

\section{Introduction}

Tobacco smoking is a major public health concern that causes high mortality and morbidity worldwide. ${ }^{1}$ The global prevalence of smoking among people aged $\geq 15$ years is estimated to be $22 \%{ }^{2}$ and counting for $\sim 5-6$ million deaths per year worldwide. ${ }^{3}$ This number is projected to increase to 10 million per year by $2030 .{ }^{4}$ In Saudi Arabia, the prevalence of smoking is variable, reaching $>50 \%$ in certain regions of the country. ${ }^{5}$ A large number of diseases are attributed to smoking. ${ }^{6,7}$ Smoking accounts for $\sim 30 \%$ of all cancer deaths in the developed countries, the majority of which is caused by lung cancer. ${ }^{8}$ In addition, smoking can cause death by influencing cardiovascular and respiratory diseases. ${ }^{9,10}$ Several commentaries written by epidemiologists indicate that tobacco smoke is a multipotent carcinogenic mixture that can cause cancers of the lower urinary tract including the renal pelvis and bladder; ${ }^{11,12}$ the upper aerodigestive tract including the oral cavity, pharynx, larynx, and esophagus; and the pancreas. ${ }^{13-18}$ To promote asthma or cancers, tobacco smoking deregulates multiple cell properties including adhesion, migration, ${ }^{19}$ and growth. ${ }^{20}$ These effects were reported with gingival
Correspondence: Abdelhabib Semlali Department of Biochemistry, College of Science, King Saud University, PO Box 2454, Riyadh I |45 I, Kingdom of Saudi Arabia

Tel +966 | 4676035

Fax +966 | 4675802

Email asemlali@ksu.edu.sa
OncoTargets and Therapy 2016:9 7187-7198

7187

Dovepress ff in 0

http://dx.doi.org/1 0.2147/OTTS109650 (c) (1) (-) 2016 Kohailan et al. This work is published and licensed by Dove Medical Press Limited. The full terms of this license are available at https://www.dovepress.com/terms.php (c) $\mathrm{BY}$ and incorporate the Creative Commons Attribution - Non Commercial (unported, v3.0) License (http://creativecommons.org/licenses/by-n/ 3.00$)$. By accessing the work you hereby accept the Terms. Non-commercial uses of the work are permitted without any further permission from Dove Medical Press Limited, provided the work is properly attributed. For permission for commercial use of this work, please see paragraphs 4.2 and 5 of our Terms (https://www.dovepress.com/terms.php). 
epithelial cells ${ }^{21}$ and fibroblasts. ${ }^{19}$ Furthermore, smoking increased epithelial cell apoptosis but decreased the repair process. ${ }^{21}$ In addition, smoking was incriminated in inducing genetic alterations in the form of DNA methylation. ${ }^{22}$ Tobacco contribution to genetic susceptibility to different diseases has been documented for 20 years, particularly for genes involved in innate immunity, which often display genetic polymorphisms and can thereby modulate the risk of cancer. ${ }^{23}$ Toll-like receptors (TLRs) are a family of receptors that play a crucial role in the innate immune response. They are transmembrane proteins that act as sensors to recognize pathogens, involved in the initiation of inflammatory responses, and play a key role in immune cell regulation, survival, and proliferation. ${ }^{24}$ In addition to their expression on sentinel cells of the immune system, they can also be found on nonimmune cells such as gingival epithelial cells. ${ }^{25}$ To date, at least 13 types of TLRs have been described in the literature ${ }^{26}$ and could be found on the cell surface or on endosomal/lysosomal compartments. ${ }^{27}$ Several studies have suggested that TLR polymorphisms are associated with inflammatory disorders. ${ }^{28,29}$ Among many discovered TLRs, TLR2 and TLR6 were found to be expressed in epithelial cells, the first type of cells being exposed to foreign agents. Together, TLR2 and TLR6 can form heterodimers that can activate MAPK and NFKB intracellular signaling pathways. ${ }^{30}$ Polymorphisms of TLR2 are associated with chronic diseases including type I diabetes and allergic asthma. ${ }^{31}$ TLR2 rs3804099 and rs3804100 single-nucleotide polymorphisms (SNPs) are associated with cancer risk and latent tuberculosis infection, respectively. ${ }^{32,33}$ TLR6 polymorphisms are associated with malaria, ulcerative colitis, and pancreatic cancer. ${ }^{34,35}$ A study reported that TLR6 rs5743810 SNP is associated with endometritis. ${ }^{36}$ TLR6 rs3796508 SNP was found to have the potential of mediating an increased risk of Klebsiella pneumoniae infection. ${ }^{37}$ The choice of these SNPs was based on their relation to different diseases, as mentioned previously, which could be explained by these SNPs' ability to alter the function of their corresponding genes. This alteration may also extend their capability to induce other unstudied diseases. The present hypothesis is that smoking-induced respiratory and cancer diseases may be mediated by nucleotide changes in certain TLRs. Importantly, no study on the effect of cigarette smoke on TLR2 and TLR6 SNPs is available. The purpose of the present study was to investigate the effect of cigarette smoke on the genotype makeup of TLR2 (rs3804100 and rs3804099) and TLR6 (rs3796508 and rs5743810) in smokers compared to nonsmokers.

\section{Materials and methods Saliva collection}

Saliva samples of 177 smokers and 126 nonsmokers were collected from male students and staff of King Saud University (KSU) during the period from January to April 2015. The participants included in this study are not suffering from any disease or disorders. Table 1 shows the clinical characteristics of the study participants. This study was ethically approved by the Research Ethics Committee of the College of Applied Medical Sciences at KSU (Approval Number: CAMS 13/3536). All the participants in this study were provided with a questionnaire, and provided written informed consent.

\section{DNA extraction}

Each saliva sample was diluted twice with phosphatebuffered saline and then immediately utilized for DNA extraction using the PureLink ${ }^{\circledR}$ Genomic DNA Mini Kit (Catalogue No K1820-01; Invitrogen ${ }^{\mathrm{TM}}$, Carlsbad, CA, USA). The DNA concentration was quantitated using a NanoDrop 8000 (Thermo Fisher Scientific, Waltham, MA, USA), and its purity was calculated using the standard A260/A280 and A260/A230 ratios.

\section{Genotyping}

Prior to genotyping, DNA samples with a final concentration of $10 \mathrm{ng} / \mu \mathrm{L}$ were prepared. Two SNPs in the TLR2 gene and two SNPs in TLR6 gene were selected: rs3804100 (1350 T/C, Ser450Ser) and rs3804099 (597 T/C, Asn199Asn) for TLR2 and rs3796508 (979 G/A, Val327Met) and rs5743810 (745 T/C, Ser249Pro) for TLR6. These SNPs were chosen based in part on a forthcoming work of the authors, wherein a link between these SNPs and colon and breast cancer development will be proved. In addition, another reason for choosing these SNPs was the locality of them in sensitive areas, controlling the expression of TLR2 and TLR6 genes. Moreover, TLR2

Table I Clinical characteristics of study subjects

\begin{tabular}{lll}
\hline Variable & Nonsmokers & Smokers \\
\hline Total collected samples & 126 & 177 \\
$\begin{array}{l}\text { Age (years; median } \pm \text { average) } \\
\text { Body mass index }\end{array}$ & $20 \pm 21$ & $24 \pm 27$ \\
$\quad$ Obese $(\geq 30)$ & & \\
$\quad$ Nonobese $(<30)$ & $20 / 100(20 \%)$ & $27 / 163(17 \%)$ \\
Years of smoking & $80 / 100(80 \%)$ & $136 / 163(83 \%)$ \\
$\quad>5$ & & \\
$\quad \leq 5$ & - & $104 / 165(63 \%)$ \\
Cigarettes per day & - & $61 / 165(37 \%)$ \\
$\quad \geq 20$ & & \\
$<20$ & - & $99 / 159(62.3 \%)$ \\
\hline
\end{tabular}


rs3804100, TLR2 rs3804099, TLR6 rs3796508, and TLR6 rs5743810 are all located in exon regions, and polymorphisms in coding regions are currently believed to be relevant to disease mechanisms by regulating gene expression (Table S1). Finally, the choice was also based on a literature review of the association of these SNPs with many diseases in different ethnic groups. Each genotyping reaction contained $5.6 \mu \mathrm{L}$ of TaqMan ${ }^{\circledR}$ Genotyping Master Mix (Applied Biosystems, Foster City, CA, USA), $0.2 \mu \mathrm{L}$ of $40 \times$ TaqMan ${ }^{\circledR}$ Genotyping SNP Assay (Applied Biosystems), and $20 \mathrm{ng}$ of DNA. The reactions were performed by using a QuantStudio ${ }^{\mathrm{TM}} 7$ Flex Real-Time PCR System (Applied Biosystems) with an end point reading of the genotypes.

\section{Statistical analysis}

As described in a previous work, ${ }^{38}$ genotypic and allelic frequencies were computed and checked for deviation from the Hardy-Weinberg equilibrium. Case-control and other genetic comparisons were performed by using the $\chi^{2}$ test and allelic odds ratios (ORs), and 95\% confidence intervals (CIs) were calculated by using Fisher's exact test (two-tailed). Statistical analyses were performed by using Statistical Package for the Social Sciences Version 22.0 for Windows. $P \leq 0.05$ was considered statistically significant.

\section{Results}

\section{Study population characteristics}

The nonsmokers and smokers were closely matched in terms of age and body mass index, and no major differences were observed within each group (Table 1). The median age was $20 \pm 21$ years for nonsmokers and $24 \pm 27$ years for smokers. Twenty percent of the nonsmokers and $17 \%$ of the smokers were obese. According to the information obtained from the questionnaires, the smokers were classified into two groups based on smoking duration: those who smoked for $>5$ years and those who smoked $\leq 5$ years. Based on the number of cigarettes smoked per day, the smokers were further classified into two categories: those who consumed $\geq 20$ cigarettes (ie, one pack or more) per day and those who consumed $<20$ cigarettes daily. Table 1 summarizes the characteristics of the participants.

\section{Candidate associations of TLR2 and TLR6 SNPs with smoking behavior}

In order to evaluate the association of genetic variation in the TLR2 and TLR6 genes with smoking behavior, two sets of saliva samples from 177 smokers and 126 nonsmokers were included in this study. Homozygous ancestral alleles in these SNPs were used as references to determine the ORs in the analysis of the genotyping results. Table 2 shows a general comparison of the allelic frequencies of the tested SNPs and ORs and statistical significances between nonsmokers and smokers. Among these SNPs, a statistically significant association of rs 5743810 in the TLR6 gene was found with smoking behavior. The genotype distribution was $11 \% \mathrm{CC}$, $28 \% \mathrm{CT}$, and $61 \% \mathrm{TT}$ in nonsmokers compared to $2 \% \mathrm{CC}$, $27 \% \mathrm{CT}$, and $71 \% \mathrm{TT}$ in smokers. The "CT" heterozygous allele showed approximately a sixfold higher correlation with smoking compared to the "CC" homozygous allele (OR =5.84; CI $=1.492-22.851 ; P=0.0061)$. The homozygous "TT" allele had approximately a sevenfold increased correlation with smoking ( $\mathrm{OR}=6.9$; $\mathrm{CI}=1.852-25.697$; $P=0.0012)$. The "CT $+\mathrm{TT}$ " genotypes, compared to the wild "CC" genotype, were found to have 6.57 -fold increased correlation with smoking ( $\mathrm{OR}=6.57$; CI $=1.783-24.179$; $P=0.0014)$. For the same SNP, significant phenotypic association with smoking was also found. The phenotype distribution was $25 \% \mathrm{C}$ and $75 \% \mathrm{~T}$ in nonsmoking patients and $16 \% \mathrm{C}$ and $84 \% \mathrm{~T}$ in smoking patients, yielding approximately a twofold increased association of the " $\mathrm{T}$ " phenotype with smoking, compared to the " $\mathrm{C}$ " phenotype (OR $=1.83$; $\mathrm{CI}=1.172-2.851 ; P=0.0074)$. No statistically significant association was found between smoking and the genetic variants of the TLR2 rs3804100, TLR2 rs3804099, and TLR6 rs3796508 SNPs in the studied population. The allele frequencies of the TLR2 rs3804100 SNP were almost the same in nonsmokers and smokers, exhibiting $82 \% \mathrm{TT}, 16 \% \mathrm{TC}$, and $2 \%$ CC. In TLR2 rs 3804099 , the alleles were distributed as $19 \% \mathrm{CC}, 45 \% \mathrm{CT}$, and $36 \% \mathrm{TT}$ in nonsmokers and $25 \% \mathrm{CC}$, $47 \% \mathrm{CT}$, and $28 \%$ TT in smokers. The alleles in the TLR6 rs 3796508 SNP were $97 \%$ GG and 3\% GA in nonsmokers and $97 \%$ GG, $2 \%$ GA, and $1 \%$ AA in smokers.

\section{Combined effect of TLR2 and TLR6 gene polymorphisms and duration of smoking}

In order to assess the selected SNPs, depending on the years of smoking, the patients were grouped as having smoked for $>5$ years (Group A) or $\leq 5$ years (Group B). Table 3 shows the genotype allocation and statistical analyses of the SNPs for both groups compared to the nonsmokers. Although TLR2 rs3804100 did not show any significant genotypic association with smoking in either group, it showed an association at the phenotypic level. The "T" phenotype, compared to the "C" phenotype, had 2.63-fold more correlation with patients who did not exceed 5 years of smoking $(\mathrm{OR}=2.63 ; \mathrm{CI}=0.979-7.040 ; P=0.0474)$. Phenotypes in this 
Table 2 Genotype frequencies of TLR2 and TLR6 gene polymorphisms in smokers and controls

\begin{tabular}{|c|c|c|c|c|c|c|c|c|}
\hline Gene & SNP & Allele & Nonsmokers & Smokers & OR & $95 \% \mathrm{Cl}$ & $\chi^{2}$ & $P$-value \\
\hline \multirow[t]{14}{*}{ TLR2 } & rs3804I00 & Total & 122 & 172 & - & - & - & - \\
\hline & & $\mathrm{TT}$ & $3(0.02)$ & $4(0.02)$ & Ref & - & - & - \\
\hline & & $\mathrm{TC}$ & $19(0.16)$ & $27(0.16)$ & 1.07 & $0.2135-5.3209$ & 0.0060 & 0.9381 \\
\hline & & $\mathrm{CC}$ & $100(0.82)$ & $|4|(0.82)$ & 1.06 & $0.2316-4.8291$ & 0.0052 & 0.9425 \\
\hline & & $\mathrm{TC}+\mathrm{CC}$ & $119(0.98)$ & $168(0.98)$ & 1.06 & $0.2327-4.8184$ & 0.0055 & 0.9411 \\
\hline & & $\mathrm{T}$ & $25(0.10)$ & $35(0.10)$ & Ref & - & - & - \\
\hline & & C & $219(0.90)$ & $309(0.90)$ & 1.01 & $0.5863-1.7323$ & 0.0008 & 0.9775 \\
\hline & rs3804099 & Total & 115 & 150 & - & - & - & - \\
\hline & & $\mathrm{CC}$ & $22(0.19)$ & $38(0.25)$ & Ref & - & - & - \\
\hline & & CT & $52(0.45)$ & $70(0.47)$ & 0.78 & $0.4 \mid 26-1.4721$ & 0.5914 & 0.4419 \\
\hline & & TT & $4 \mathrm{I}(0.36)$ & $42(0.28)$ & 0.59 & $0.3008-1.1693$ & 2.2901 & 0.1302 \\
\hline & & $\mathrm{CT}+\mathrm{TT}$ & $93(0.8 I)$ & $112(0.75)$ & 0.70 & $0.3854-1.2612$ & 1.4299 & 0.2318 \\
\hline & & C & $96(0.42)$ & I 46 (0.49) & Ref & - & - & - \\
\hline & & $\mathrm{T}$ & $134(0.58)$ & I54 (0.5I) & 0.76 & $0.5345-1.0684$ & $2.5|8|$ & 0.1125 \\
\hline \multirow[t]{14}{*}{ TLR6 } & rs3796508 & Total & 118 & 170 & - & - & - & - \\
\hline & & GG & $115(0.97)$ & $165(0.97)$ & Ref & - & - & - \\
\hline & & $\mathrm{GA}$ & $3(0.03)$ & $4(0.02)$ & 0.93 & $0.204 \mid-4.23 I I$ & 0.0090 & 0.9244 \\
\hline & & AA & $0(0.00)$ & I (0.0I) & - & - & 0.6952 & 0.4044 \\
\hline & & $\mathrm{GA}+\mathrm{AA}$ & $3(0.03)$ & $5(0.03)$ & 1.16 & $0.2722-4.9573$ & 0.0410 & 0.8395 \\
\hline & & G & $233(0.99)$ & $334(0.98)$ & Ref & - & - & - \\
\hline & & $A$ & $3(0.01)$ & $6(0.02)$ & 1.40 & $0.3454-5.6352$ & 0.2206 & 0.6386 \\
\hline & rs5743810 & Total & 97 & 157 & - & - & - & - \\
\hline & & $\mathrm{CC}$ & II (0.II) & $3(0.02)$ & Ref & - & - & - \\
\hline & & CT & $27(0.28)$ & $43(0.27)$ & 5.84 & $1.4923-22.8505$ & 7.5350 & $0.006 I^{*}$ \\
\hline & & TT & $59(0.61)$ & II (0.7I) & 6.90 & $|.85| 8-25.697 \mid$ & 10.5594 & $0.0012^{* *}$ \\
\hline & & $\mathrm{CT}+\mathrm{TT}$ & $86(0.89)$ & $154(0.98)$ & 6.57 & I.7830-24.1792 & 10.2360 & $0.0014^{* *}$ \\
\hline & & C & $49(0.25)$ & $49(0.16)$ & Ref & - & - & - \\
\hline & & $\mathrm{T}$ & $145(0.75)$ & $265(0.84)$ & 1.83 & $1.1715-2.8512$ & 7.1759 & $0.0074 *$ \\
\hline
\end{tabular}

Notes: $* P<0.05, * * P<0.005$. Values in parentheses are frequencies. Values in bold represent significant results.

Abbreviations: $\mathrm{Cl}$, confidence interval; OR, odds ratio; SNP, single-nucleotide polymorphism; TLR, toll-like receptor; Ref, reference.

SNP for Group B were distributed as $10 \% \mathrm{C}$ and $90 \% \mathrm{~T}$ in nonsmokers and $4 \% \mathrm{C}$ and $96 \% \mathrm{~T}$ in smokers. This relationship was observed neither in the general comparison nor in Group A. Phenotypes for the same SNP in Group A were distributed at $10 \% \mathrm{C}$ and $90 \% \mathrm{~T}$ in nonsmokers and $15 \% \mathrm{C}$ and $85 \% \mathrm{~T}$ in smokers. Surprisingly, the rs $3804099 \mathrm{SNP}$ in the TLR2 gene (which did not show significant association in the general comparison, as shown in Table 2) showed statistically significant results in long-term smokers (Group A) compared to nonsmokers. The genotype distribution for the rs 3804099 SNP was $19 \% \mathrm{CC}, 45 \% \mathrm{CT}$, and $36 \%$ TT in nonsmokers and $31 \% \mathrm{CC}, 45 \% \mathrm{CT}$, and $24 \%$ TT in smokers. Unlike the heterozygous " $\mathrm{CT}$ " allele, the homozygous "TT" allele appears to have 2.5 -fold protection association with smoking compared to the "CC" homozygous reference allele $(\mathrm{OR}=0.4 ; \mathrm{CI}=0.187-0.867 ; P=0.0189)$. The combination of the two alleles "CT $+\mathrm{TT}$ " also had approximately twofold higher protection association ( $\mathrm{OR}=0.52 ; \mathrm{CI}=0.27-0.982$; $P=0.0423$ ). The phenotypes were distributed at $42 \% \mathrm{C}$ and $58 \% \mathrm{~T}$ in nonsmokers and 54\% $\mathrm{C}$ and $46 \% \mathrm{~T}$ in smokers. The " $\mathrm{T}$ " phenotype had $\sim 1.64$-fold more protection correlation with long-term smokers, compared to the wild "C" phenotype (OR $=0.61 ; \mathrm{CI}=0.413-0.908 ; P=0.0144)$. However, no association was detected between this SNP and short-term smoking (Group B). As in the overall study, the TLR6 rs3796508 SNP showed no significant association with long- or short-term smoking. In Group A, the genotypes were divided into $97 \%$ GG and 3\% GA in nonsmokers and 98\% GG and 2\% GA in smokers. However, the phenotypes were sorted into $99 \% \mathrm{G}$ and $1 \% \mathrm{~A}$ in the nonsmokers and the smokers. In Group B, the genotype distribution for this SNP was $97 \% \mathrm{GG}$ and $3 \% \mathrm{GA}$ in nonsmokers and $95 \% \mathrm{GG}, 3 \%$ $\mathrm{GA}$, and $2 \% \mathrm{AA}$ in smokers. The phenotypes were allocated as $99 \% \mathrm{G}$ and $1 \% \mathrm{~A}$ in nonsmokers and $97 \% \mathrm{G}$ and $3 \% \mathrm{~A}$ in smokers. TLR6 rs5743810, as in the general comparison, also showed a statistically significant correlation with long-term smoking. The genotype distribution for this SNP in Group A was $11 \% \mathrm{CC}, 28 \% \mathrm{CT}$, and $61 \%$ TT in nonsmoking patients and $1 \% \mathrm{CC}, 24 \% \mathrm{CT}$, and $75 \% \mathrm{TT}$ in smoking patients. Compared to the "CC" homozygous reference allele, the "CT" heterozygous allele showed approximately ninefold higher association with smoking ( $\mathrm{OR}=8.96 ; \mathrm{CI}=1.073-74.907$; 
Table 3 Comparison of genotype frequencies of TLR2 and TLR6 gene SNPs with overall controls depending on smoking duration

\begin{tabular}{|c|c|c|c|c|c|c|c|c|}
\hline Gene & SNP & Allele & Nonsmokers & $>5$ years & OR & $95 \% \mathrm{Cl}$ & $x^{2}$ & $P$-value \\
\hline \multicolumn{9}{|c|}{ Patients smoking for $>5$ years } \\
\hline \multirow[t]{14}{*}{ TLR2 } & rs3804100 & Total & 122 & 102 & - & - & - & - \\
\hline & & TT & $3(0.02)$ & $4(0.04)$ & Ref & - & - & - \\
\hline & & $\mathrm{TC}$ & $19(0.16)$ & $22(0.22)$ & 0.87 & $0.1722-4.3792$ & 0.0292 & 0.8642 \\
\hline & & $\mathrm{CC}$ & $100(0.82)$ & $76(0.75)$ & 0.57 & $0.1239-2.6229$ & 0.5333 & 0.4652 \\
\hline & & $\mathrm{TC}+\mathrm{CC}$ & $119(0.98)$ & $98(0.96)$ & 0.62 & $0.1350-2.8259$ & 0.3925 & 0.5310 \\
\hline & & $\mathrm{T}$ & $25(0.10)$ & $30(0.15)$ & Ref & - & - & - \\
\hline & & $\mathrm{C}$ & $219(0.90)$ & $174(0.85)$ & 0.66 & $0.3756-1.167 \mid$ & 2.0521 & 0.1520 \\
\hline & rs3804099 & Total & 115 & 89 & - & - & - & - \\
\hline & & $\mathrm{CC}$ & $22(0.19)$ & $28(0.3 \mathrm{I})$ & Ref & - & - & - \\
\hline & & CT & $52(0.45)$ & $40(0.45)$ & 0.60 & $0.3019-1.2099$ & 2.0353 & 0.1537 \\
\hline & & TT & $4 \mathrm{I}(0.36)$ & $21(0.24)$ & 0.40 & $0.1869-0.8667$ & 5.5077 & $0.0189 *$ \\
\hline & & $\mathrm{CT}+\mathrm{TT}$ & $93(0.81)$ & $61(0.69)$ & 0.52 & $0.2704-0.9823$ & 4.1226 & $0.0423 *$ \\
\hline & & C & $96(0.42)$ & $96(0.54)$ & Ref & - & - & - \\
\hline & & $\mathrm{T}$ & $134(0.58)$ & $82(0.46)$ & 0.61 & $0.4125-0.9078$ & 5.9883 & $0.0144^{*}$ \\
\hline \multirow[t]{14}{*}{ TLR6 } & rs3796508 & Total & 118 & 99 & - & - & - & - \\
\hline & & GG & II5 (0.97) & $97(0.98)$ & Ref & - & - & - \\
\hline & & GA & $3(0.03)$ & $2(0.02)$ & 0.79 & $0.1294-4.8272$ & 0.0652 & 0.7984 \\
\hline & & AA & $0(0.00)$ & $0(0.00)$ & - & - & - & - \\
\hline & & $\mathrm{GA}+\mathrm{AA}$ & $3(0.03)$ & $2(0.02)$ & 0.79 & $0.1294-4.8272$ & 0.0652 & 0.7984 \\
\hline & & $\mathrm{G}$ & $233(0.99)$ & $196(0.99)$ & Ref & - & - & - \\
\hline & & $A$ & $3(0.01)$ & $2(0.01)$ & 0.79 & $0.1311-4.7910$ & 0.0644 & 0.7996 \\
\hline & rs57438I0 & Total & 97 & 91 & - & - & - & - \\
\hline & & $\mathrm{CC}$ & II (0.II) & I (0.0I) & Ref & - & - & - \\
\hline & & CT & $27(0.28)$ & $22(0.24)$ & 8.96 & $1.0725-74.9067$ & 5.4868 & $0.0192 *$ \\
\hline & & $\mathrm{TT}$ & $59(0.6 \mathrm{I})$ & $68(0.75)$ & 12.68 & I.5892-101.1402 & 8.9644 & $0.0028 * *$ \\
\hline & & $\mathrm{CT}+\mathrm{TT}$ & $86(0.89)$ & $90(0.99)$ & $|1.5|$ & I.4550-91.0798 & 8.2411 & $0.004 I * *$ \\
\hline & & C & $49(0.25)$ & $24(0.13)$ & Ref & - & - & - \\
\hline & & $\mathrm{T}$ & $145(0.75)$ & $158(0.87)$ & 2.22 & $1.2992-3.8094$ & 8.7453 & $0.003 I * *$ \\
\hline \multicolumn{9}{|c|}{ Patients smoking for $\leq 5$ years } \\
\hline \multirow[t]{14}{*}{ TLR2 } & rs3804100 & Total & 122 & 60 & - & - & - & - \\
\hline & & TT & $3(0.02)$ & $0(0.00)$ & Ref & - & - & - \\
\hline & & $\mathrm{TC}$ & $19(0.16)$ & $5(0.08)$ & - & - & 0.7670 & 0.3811 \\
\hline & & $\mathrm{CC}$ & $100(0.82)$ & $55(0.92)$ & - & - & 1.6329 & 0.2013 \\
\hline & & $\mathrm{TC}+\mathrm{CC}$ & $119(0.98)$ & $60(1.00)$ & - & - & 1.5001 & 0.2207 \\
\hline & & $\mathrm{T}$ & $25(0.10)$ & $5(0.04)$ & Ref & - & - & - \\
\hline & & C & $219(0.90)$ & $115(0.96)$ & 2.63 & $0.979 \mid-7.0404$ & 3.9310 & $0.0474 *$ \\
\hline & rs3804099 & Total & 115 & 52 & - & - & - & - \\
\hline & & $\mathrm{CC}$ & $22(0.19)$ & $8(0.15)$ & Ref & - & - & - \\
\hline & & CT & $52(0.45)$ & $25(0.48)$ & 1.32 & $0.5168-3.3824$ & 0.3406 & 0.5595 \\
\hline & & $\mathrm{TT}$ & $41(0.36)$ & $19(0.37)$ & 1.27 & $0.4807-3.3788$ & 0.2381 & 0.6256 \\
\hline & & $\mathrm{CT}+\mathrm{TT}$ & $93(0.8 \mathrm{I})$ & $44(0.85)$ & 1.30 & $0.5369-3.1529$ & 0.3409 & 0.5593 \\
\hline & & C & $96(0.42)$ & $4 I(0.39)$ & Ref & - & - & - \\
\hline & & $\mathrm{T}$ & I34 (0.58) & $63(0.61)$ & 1.10 & $0.6862-1.7659$ & 0.1588 & 0.6903 \\
\hline \multirow[t]{14}{*}{ TLR6 } & rs3796508 & Total & 118 & 61 & - & - & - & - \\
\hline & & GG & $115(0.97)$ & $58(0.95)$ & Ref & - & - & - \\
\hline & & GA & $3(0.03)$ & $2(0.03)$ & 1.32 & $0.2148-8.1326$ & 0.0911 & 0.7627 \\
\hline & & AA & $0(0.00)$ & I (0.02) & - & - & - & - \\
\hline & & $\mathrm{GA}+\mathrm{AA}$ & $3(0.03)$ & $3(0.05)$ & 1.98 & $0.3880-10.1316$ & 0.7005 & 0.4026 \\
\hline & & G & $233(0.99)$ & $118(0.97)$ & Ref & - & - & - \\
\hline & & $A$ & $3(0.01)$ & $4(0.03)$ & 2.63 & $0.5797-11.9568$ & 1.6907 & 0.1935 \\
\hline & rs5743810 & Total & 97 & 56 & - & - & - & - \\
\hline & & $\mathrm{CC}$ & II (0.II) & $2(0.04)$ & Ref & - & - & - \\
\hline & & CT & $27(0.28)$ & $17(0.30)$ & 3.46 & $0.6824-17.5738$ & 2.4414 & 0.1182 \\
\hline & & $\mathrm{TT}$ & $59(0.61)$ & $37(0.66)$ & 3.45 & $0.7235-16.4422$ & 2.6721 & 0.1021 \\
\hline & & $\mathrm{CT}+\mathrm{TT}$ & $86(0.89)$ & $54(0.96)$ & 3.45 & $0.7370-16.1837$ & 2.7560 & 0.0969 \\
\hline & & C & $49(0.25)$ & $21(0.19)$ & Ref & - & - & - \\
\hline & & $\mathrm{T}$ & $145(0.75)$ & $91(0.81)$ & 1.46 & $0.8244-2.6011$ & 1.7045 & 0.1917 \\
\hline
\end{tabular}

Notes: $* P<0.05, * * P<0.05$. Values in parentheses are frequencies. Values in bold represent significant results.

Abbreviations: $\mathrm{Cl}$, confidence interval; OR, odds ratio; SNP, single-nucleotide polymorphism; TLR, toll-like receptor; Ref, reference. 
$P=0.0192$ ), whereas the homozygous "TT" showed more than 12-fold stronger correlation with cigarette smoke $(\mathrm{OR}=12.68 ; \mathrm{CI}=1.589-101.14 ; P=0.0028)$. In addition, the two variants together, "CT + TT," had 11.51-fold more correlation with smoking $(\mathrm{OR}=11.51$; $\mathrm{CI}=1.455-91.08$; $P=0.0041)$. The phenotype allocation for this SNP was $25 \% \mathrm{C}$ and $75 \% \mathrm{~T}$ in nonsmokers and $13 \% \mathrm{C}$ and $87 \% \mathrm{~T}$ in smokers. Compared to the "C" phenotype, the " $\mathrm{T}$ " phenotype had more than twofold association with long-term smokers ( $\mathrm{OR}=2.22 ; \mathrm{CI}=1.299-3.809 ; P=0.0031)$. In contrast, no association was observed between this SNP and short-term smoking. In Group B, the genotype frequencies for this SNP were $11 \% \mathrm{CC}, 28 \% \mathrm{CT}$, and $61 \% \mathrm{TT}$ in nonsmokers and $4 \% \mathrm{CC}, 30 \% \mathrm{CT}$, and 66\% TT in smokers. The phenotypes were $25 \% \mathrm{C}$ and $75 \% \mathrm{~T}$ in nonsmokers and $19 \% \mathrm{C}$ and $81 \%$ $\mathrm{T}$ in smokers.

\section{Association between SNPs and heavy smoking}

Based on the intensity of smoking, the smokers were classified into two groups: heavy smokers who consumed $\geq 20$ cigarettes daily (ie, approximately one pack; Category A) and those who consumed $<20$ cigarettes per day (Category B). Table 4 shows the genotype frequencies of the selected SNPs for both categories compared to the overall controls. A statistically significant association of the rs5743810 SNP in the TLR6 gene with smokers from Category A was found. The allele frequencies were $11 \% \mathrm{CC}, 28 \% \mathrm{CT}$, and $61 \%$ TT in nonsmokers and 2\% CC, $26 \%$ CT, and $72 \%$ TT in smokers. Compared to the "CC" homozygous reference allele, the "CT" heterozygous allele had more than fourfold association with smoking ( $\mathrm{OR}=4.69$; $\mathrm{CI}=0.94-23.346$; $P=0.0444)$, whereas the "TT" homozygous allele had a sixfold increase in correlation with smoking $(\mathrm{OR}=5.97$; $\mathrm{CI}$ $=1.269-28.043 ; P=0.0119)$. A combination of the two alleles, "CT + TT," had 5.56-fold more correlation with smokers from Category A (OR =5.56; $\mathrm{CI}=1.198-25.846 ; P=0.0151)$. The phenotypes were distributed as $25 \% \mathrm{C}$ and $75 \% \mathrm{~T}$ in nonsmokers and 15\% $\mathrm{C}$ and $85 \% \mathrm{~T}$ in smokers. Compared to the "C" phenotype, the "T" phenotype had approximately twofold more association with smoking (OR =1.89; CI $=1.121-3.186 ; P=0.0159)$. However, the same SNP showed an association with smokers in Category B, but only at the genotypic level. In fact, the genotype distribution was $11 \%$ CC, $28 \% \mathrm{CT}$, and $61 \%$ TT in nonsmokers and $2 \% \mathrm{CC}, 30 \%$ $\mathrm{CT}$, and 68\% TT in smokers. The "TT" homozygous allele, compared to the reference "CC," appeared to have more than sixfold increased correlation with smoking $(\mathrm{OR}=6.71$;
$\mathrm{CI}=0.831-54.194 ; P=0.0425)$, whereas a combination of "CT" and "TT" alleles showed slightly lower association with smoking $(\mathrm{OR}=6.65 ; \mathrm{CI}=0.834-53.022 ; P=0.0414)$. The phenotypes were $25 \% \mathrm{C}$ and $75 \% \mathrm{~T}$ in nonsmokers and $17 \% \mathrm{C}$ and $83 \% \mathrm{~T}$ in smokers. In contrast, no considerable association was found for both the categories in the other SNPs. The genotype distribution of the TLR2 rs3804100 SNP in smokers from Category A was $82 \% \mathrm{TT}, 16 \% \mathrm{TC}$, and $2 \% \mathrm{CC}$ in nonsmokers and $81 \% \mathrm{TT}, 18 \% \mathrm{TC}$, and $1 \%$ $\mathrm{CC}$ in smokers. In Category B, the distribution of TLR2 rs 3804100 was $82 \%$ TT, $16 \%$ TC, and $2 \%$ CC in nonsmokers and $79 \% \mathrm{TT}, 16 \% \mathrm{TC}$, and 5\% CC in smokers. The allele frequencies of the TLR2 rs3804099 SNP in Category A were $19 \% \mathrm{CC}, 45 \% \mathrm{CT}$, and $36 \% \mathrm{TT}$ in nonsmokers and $28 \%$ CC, $42 \%$ CT, and 30\% TT in smokers. In Category B, they were $19 \% \mathrm{CC}, 45 \% \mathrm{CT}$, and $36 \%$ TT in nonsmokers and $23 \% \mathrm{CC}, 51 \% \mathrm{CT}$, and $26 \%$ TT in smokers. The genotypes of the TLR6 rs3796508 SNP in Category A were 97\% GG and $3 \% \mathrm{GA}$ in nonsmokers and $99 \% \mathrm{GG}$ and $1 \% \mathrm{GA}$ in smokers. In Category B, the genotype allocation was 97\% GG and 3\% GA in nonsmokers and 94.74\% GG, 3.51\% GA, and $1.75 \%$ AA in smokers.

\section{Comparison of the results of the present study with that of others from different populations}

A comparison between the selected SNPs from the present results of the Saudi population and those from the other studies, performed across different populations, obtained from the literature, was made to clarify the relationships that link these populations together (Table 5). ${ }^{39}$ Regarding the TLR2 rs3804100 SNP, Chinese (HCB) and Kenyan (MKK) populations were significantly different from the sample population of the present study. Moreover, the MKK population, along with the Japanese (JPT) and Nigerian (YRI) populations, was different in terms of the TLR2 rs3804099 SNP. For TLR6 rs3796508, all studied populations showed similar allele distributions to the Saudi population. However, these populations were completely different from the target population for the TLR6 rs5743810 SNP. As shown in Figure 1, regional linkage disequilibrium (LD) plot was established using SNP Annotation and Proxy Search (http://www.broadinstitute.org/ mpg/snap/ldplot.php). The maximum $r^{2}$ values for the SNPs studied were 0.48 for rs3804100, 0.684 for rs3804099, and 0.901 for rs5743810 (Figure 1A-C). The regional association LD plot showed several positions near the rs5743810 SNP with high LD $\left(r^{2}=0.901\right)$. The rs5743810 SNP also showed close association with TLR10 and TLR1 (Figure 1C). 
Table 4 Genotype frequencies of TLR2 and TLR6 gene SNPs with overall controls according to the daily quantity of cigarettes

\begin{tabular}{|c|c|c|c|c|c|c|c|c|}
\hline Gene & SNP & Allele & Nonsmokers & $\geq 20$ cigarettes & OR & $95 \% \mathrm{Cl}$ & $x^{2}$ & $P$-value \\
\hline \multicolumn{9}{|c|}{ Patients smoking $\geq 20$ cigarettes/day } \\
\hline \multirow[t]{14}{*}{ TLR2 } & rs3804100 & Total & 122 & 98 & - & - & - & - \\
\hline & & TT & $3(0.02)$ & $\mathrm{I}(0.0 \mathrm{I})$ & Ref & - & - & - \\
\hline & & TC & $19(0.16)$ & $18(0.18)$ & 2.84 & $0.2702-29.8978$ & 0.8119 & 0.3676 \\
\hline & & $\mathrm{CC}$ & $100(0.82)$ & $79(0.8 \mathrm{I})$ & 2.37 & $0.2418-23.2255$ & 0.5822 & 0.4455 \\
\hline & & $\mathrm{TC}+\mathrm{CC}$ & $119(0.98)$ & $97(0.99)$ & 2.45 & $0.2504-23.8847$ & 0.6301 & 0.4273 \\
\hline & & $\mathrm{T}$ & $25(0.10)$ & $20(0.10)$ & Ref & - & - & - \\
\hline & & C & $219(0.90)$ & $176(0.90)$ & 1.00 & $0.540 \mathrm{I}-\mathrm{I} .8685$ & 0.0002 & 0.9885 \\
\hline & rs3804099 & Total & 115 & 83 & - & - & - & - \\
\hline & & $\mathrm{CC}$ & $22(0.19)$ & $23(0.28)$ & Ref & - & - & - \\
\hline & & CT & $52(0.45)$ & $35(0.42)$ & 0.64 & $0.3119-1.3290$ & 1.4256 & 0.2325 \\
\hline & & $\mathrm{TT}$ & $41(0.36)$ & $25(0.30)$ & 0.58 & $0.2707-1.2565$ & 1.9088 & 0.1671 \\
\hline & & $\mathrm{CT}+\mathrm{TT}$ & $93(0.81)$ & $60(0.72)$ & 0.62 & $0.3162-1.2043$ & 2.0209 & 0.1551 \\
\hline & & C & $96(0.42)$ & $81(0.49)$ & Ref & - & - & - \\
\hline & & $\mathrm{T}$ & $134(0.58)$ & $85(0.5 \mathrm{I})$ & 0.75 & $0.503 \mathrm{I}-\mathrm{I} .1234$ & 1.9419 & 0.1635 \\
\hline \multirow[t]{14}{*}{ TLR6 } & rs3796508 & Total & 118 & 97 & - & - & - & - \\
\hline & & GG & II 5 (0.97) & $96(0.99)$ & Ref & - & - & - \\
\hline & & GA & $3(0.03)$ & $\mathrm{I}(0.0 \mathrm{I})$ & 0.40 & $0.0409-3.9014$ & 0.6661 & 0.4144 \\
\hline & & AA & $0(0.00)$ & $0(0.00)$ & - & - & - & - \\
\hline & & $\mathrm{GA}+\mathrm{AA}$ & $3(0.03)$ & I $(0.01)$ & 0.40 & $0.0409-3.9014$ & 0.6661 & 0.4144 \\
\hline & & G & $233(0.99)$ & $193(0.99)$ & Ref & - & - & - \\
\hline & & $A$ & $3(0.01)$ & $\mathrm{I}(0.0 \mathrm{I})$ & 0.40 & $0.0415-3.9000$ & 0.6598 & 0.4166 \\
\hline & rs57438I0 & Total & 97 & 89 & - & - & - & - \\
\hline & & $\mathrm{CC}$ & II (0.II) & $2(0.02)$ & Ref & - & - & - \\
\hline & & СТ & $27(0.28)$ & $23(0.26)$ & 4.69 & $0.9402-23.3463$ & 4.0403 & $0.0444^{*}$ \\
\hline & & TT & $59(0.61)$ & $64(0.72)$ & 5.97 & $1.2693-28.0427$ & 6.3218 & $0.0119^{*}$ \\
\hline & & $\mathrm{CT}+\mathrm{TT}$ & $86(0.89)$ & $87(0.98)$ & 5.56 & I.1978-25.8463 & 5.9034 & $0.015 I^{*}$ \\
\hline & & C & $49(0.25)$ & $27(0.15)$ & Ref & - & - & - \\
\hline & & $\mathrm{T}$ & $145(0.75)$ & $151(0.85)$ & 1.89 & $1.1212-3.1856$ & 5.8126 & $0.0159 *$ \\
\hline \multicolumn{9}{|c|}{ Patients smoking $<20$ cigarettes/day } \\
\hline \multirow[t]{14}{*}{ TLR2 } & rs3804100 & Total & 122 & 58 & - & - & - & - \\
\hline & & TT & $3(0.02)$ & $3(0.05)$ & Ref & - & - & - \\
\hline & & TC & $19(0.16)$ & $9(0.16)$ & 0.47 & $0.0794-2.8260$ & 0.6899 & 0.4062 \\
\hline & & $\mathrm{CC}$ & $100(0.82)$ & $46(0.79)$ & 0.46 & $0.0894-2.3666$ & 0.9023 & 0.3422 \\
\hline & & $\mathrm{TC}+\mathrm{CC}$ & $119(0.98)$ & $55(0.95)$ & 0.46 & $0.0904-2.3635$ & 0.8982 & 0.3433 \\
\hline & & $\mathrm{T}$ & $25(0.10)$ & $15(0.13)$ & Ref & - & - & - \\
\hline & & C & $219(0.90)$ & $101(0.87)$ & 0.77 & $0.3886-1.5205$ & 0.5739 & 0.4487 \\
\hline & rs3804099 & Total & 115 & 53 & - & - & - & - \\
\hline & & $\mathrm{CC}$ & $22(0.19)$ & $12(0.23)$ & Ref & - & - & - \\
\hline & & CT & $52(0.45)$ & $27(0.5 \mathrm{I})$ & 0.95 & $0.4097-2.2120$ & 0.0131 & 0.9088 \\
\hline & & TT & $4 \mathrm{I}(0.36)$ & $14(0.26)$ & 0.63 & $0.2473-1.5849$ & 0.9837 & 0.3213 \\
\hline & & $\mathrm{CT}+\mathrm{TT}$ & $93(0.81)$ & $4 \mathrm{I}(0.77)$ & 0.81 & $0.3655-1.7873$ & 0.277 I & 0.5986 \\
\hline & & C & $96(0.42)$ & $51(0.48)$ & Ref & - & - & - \\
\hline & & $\mathrm{T}$ & I $34(0.58)$ & $55(0.52)$ & 0.77 & $0.4865-1.2269$ & 1.1979 & 0.2737 \\
\hline \multirow[t]{14}{*}{ TLR6 } & rs3796508 & Total & 118 & 57 & - & - & - & - \\
\hline & & GG & II $5(0.97)$ & $54(0.95)$ & Ref & - & - & - \\
\hline & & GA & $3(0.03)$ & $2(0.04)$ & 1.42 & $0.2304-8.7468$ & 0.1441 & 0.7042 \\
\hline & & AA & $0(0.00)$ & I (0.02) & - & - & - & - \\
\hline & & $\mathrm{GA}+\mathrm{AA}$ & $3(0.03)$ & $3(0.05)$ & 2.13 & $0.4|6|-10.8984$ & 0.8593 & 0.3539 \\
\hline & & G & $233(0.99)$ & $110(0.96)$ & Ref & - & - & - \\
\hline & & $A$ & $3(0.01)$ & $4(0.04)$ & 2.82 & $0.6214-12.8365$ & 1.9636 & 0.1611 \\
\hline & rs5743810 & Total & 97 & 53 & - & - & - & - \\
\hline & & $\mathrm{CC}$ & II (0.II) & I (0.02) & Ref & - & - & - \\
\hline & & CT & $27(0.28)$ & $16(0.30)$ & 6.52 & $0.768 I-55.32 I 2$ & 3.6631 & 0.0556 \\
\hline & & TT & $59(0.61)$ & $36(0.68)$ & 6.71 & $0.8313-54.1942$ & 4.1157 & $0.0425^{*}$ \\
\hline & & $\mathrm{CT}+\mathrm{TT}$ & $86(0.89)$ & $52(0.98)$ & 6.65 & $0.8343-53.0215$ & 4.1616 & $0.0414^{*}$ \\
\hline & & C & $49(0.25)$ & $18(0.17)$ & Ref & - & - & - \\
\hline & & $\mathrm{T}$ & $145(0.75)$ & $88(0.83)$ & 1.65 & $0.9052-3.0153$ & $2.707 \mid$ & 0.0999 \\
\hline
\end{tabular}

Notes: $* P<0.05, * * P<0.01$. Values in parentheses are frequencies. Values in bold represent significant results.

Abbreviations: $\mathrm{Cl}$, confidence interval; OR, odds ratio; SNP, single-nucleotide polymorphism; TLR, toll-like receptor; Ref, reference. 
Table 5 Allele and genotype frequencies of TLR2 and TLR6 gene polymorphisms in Riyadh region compared to other populations

\begin{tabular}{|c|c|c|c|c|c|c|c|}
\hline \multirow[t]{2}{*}{ Population } & \multicolumn{3}{|c|}{ Genotype frequency $(\mathbf{N})$} & \multicolumn{2}{|c|}{ Allele frequency } & \multirow[t]{2}{*}{$x^{2}$} & \multirow[t]{2}{*}{$P$-value } \\
\hline & TT & CT & CC & $\mathbf{T}$ & C & & \\
\hline \multicolumn{8}{|l|}{ TLR2 rs3804100 } \\
\hline CRS $(n=122)$ & $0.820(100)$ & $0.156(19)$ & $0.025(3)$ & 0.898 & 0.102 & - & - \\
\hline CEU $(n=226)$ & $0.850(192)$ & $0.150(34)$ & - & 0.925 & 0.075 & 0.7712 & 0.3799 \\
\hline $\mathrm{HCB}(n=86)$ & $0.372(32)$ & $0.581(50)$ & $0.047(4)$ & 0.663 & 0.337 & 17.3795 & $<0.005$ \\
\hline JPT $(n=166)$ & $0.578(96)$ & $0.410(68)$ & $0.012(2)$ & 0.783 & 0.217 & 6.5853 & 0.0103 \\
\hline YRI $(n=226)$ & $0.876(198)$ & $0.124(28)$ & - & 0.938 & 0.062 & 1.8428 & 0.1746 \\
\hline $\operatorname{MEX}(n=100)$ & $0.820(82)$ & $0.180(18)$ & - & 0.91 & 0.09 & 0.0975 & 0.7548 \\
\hline MKK (n=286) & $0.951(272)$ & $0.049(14)$ & - & 0.976 & 0.024 & 11.6448 & $<0.005$ \\
\hline TSI $(n=176)$ & $0.875(154)$ & $0.125(22)$ & - & 0.938 & 0.062 & $\mathrm{I} .6293$ & 0.2018 \\
\hline \multicolumn{8}{|l|}{ TLR2 rs3804099 } \\
\hline CRS $(n=115)$ & 0.191 (22) & $0.452(52)$ & $0.357(4 \mathrm{I})$ & 0.417 & 0.583 & - & - \\
\hline CEU (n=224) & $0.170(38)$ & $0.562(126)$ & $0.268(60)$ & 0.451 & 0.549 & 0.3484 & 0.5550 \\
\hline $\mathrm{HCB}(\mathrm{n}=86)$ & $0.047(4)$ & $0.651(56)$ & $0.302(26)$ & 0.372 & 0.628 & 0.4231 & 0.5154 \\
\hline JPT $(n=172)$ & $0.070(12)$ & $0.395(68)$ & $0.535(92)$ & 0.267 & 0.733 & 7.0803 & 0.0078 \\
\hline YRI $(n=226)$ & $0.416(94)$ & $0.425(96)$ & $0.159(36)$ & 0.628 & 0.372 & 13.7006 & $<0.005$ \\
\hline $\operatorname{MEX}(n=100)$ & $0.100(10)$ & $0.500(50)$ & $0.400(40)$ & 0.350 & 0.650 & 1.0249 & 0.3114 \\
\hline MKK (n=286) & $0.385(110)$ & $0.503(144)$ & $0.112(32)$ & 0.636 & 0.364 & 16.0233 & $<0.005$ \\
\hline TSI $(n=176)$ & $0.193(34)$ & $0.477(84)$ & $0.330(58)$ & 0.432 & 0.568 & 0.0607 & 0.8054 \\
\hline \multicolumn{8}{|l|}{ TLR6 rs3796508 } \\
\hline CRS $(n=|| 8)$ & - & $0.03(3)$ & $0.97(115)$ & 0.987 & 0.013 & - & - \\
\hline CEU $(n=116)$ & - & - & $1.000(116)$ & 1.000 & - & I.484| & 0.2231 \\
\hline $\mathrm{HCB}(n=86)$ & - & $0.116(10)$ & $0.884(76)$ & 0.942 & 0.058 & 3.3134 & 0.0687 \\
\hline JPT $(n=172)$ & - & $0.116(20)$ & $0.884(152)$ & 0.942 & 0.058 & 3.7768 & 0.0520 \\
\hline YRI $(n=226)$ & - & $0.035(8)$ & $0.965(218)$ & 0.982 & 0.018 & 0.1361 & 0.7121 \\
\hline MEX & - & - & - & - & - & - & - \\
\hline MKK $(n=286)$ & - & $0.049(14)$ & $0.95 I(272)$ & 0.976 & 0.024 & 0.5250 & 0.4687 \\
\hline TSI $(n=176)$ & - & $0.011(2)$ & $0.989(174)$ & 0.994 & 0.006 & 0.3692 & 0.5434 \\
\hline \multicolumn{8}{|l|}{ TLR6 rs5743810 } \\
\hline CRS ( $n=97)$ & $0.113(11)$ & $0.278(27)$ & $0.608(59)$ & 0.253 & 0.747 & - & - \\
\hline CEU $(n=224)$ & $0.304(68)$ & $0.464(104)$ & $0.232(52)$ & 0.536 & 0.464 & 21.9658 & $<0.005$ \\
\hline $\mathrm{HCB}(\mathrm{n}=90)$ & $1.000(90)$ & - & - & 1.000 & - & 109.8613 & $<0.005$ \\
\hline JPT (n=88) & $1.000(88)$ & - & - & 1.000 & - & 108.1604 & $<0.005$ \\
\hline YRI $(n=120)$ & $1.000(120)$ & - & - & 1.000 & - & 134.6913 & $<0.005$ \\
\hline $\operatorname{MEX}(n=100)$ & $0.660(66)$ & $0.300(30)$ & $0.040(4)$ & 0.810 & 0.190 & 61.5083 & $<0.005$ \\
\hline MKK $(n=286)$ & $0.818(234)$ & $0.175(50)$ & $0.007(2)$ & 0.906 & 0.094 & $|60.945|$ & $<0.005$ \\
\hline TSI $(n=176)$ & $0.477(84)$ & $0.375(66)$ & $0.148(26)$ & 0.665 & 0.335 & 42.6049 & $<0.005$ \\
\hline
\end{tabular}

Note: Data from The International HapMap Project. ${ }^{39}$

Abbreviations: TLR, toll-like receptor; CRS, central region population of Saudi Arabia; CEU, Utah residents with northern and western European ancestry from the CEPH collection; CEPH, Centre d'Etude du Polymorphisme Humain; HCB, Han Chinese in Beijing, China; JPT, Japanese in Tokyo, Japan; YRI, Yoruba in Ibadan, Nigeria; MEX, Mexican ancestry in Los Angeles, California; MKK, Maasai in Kinyawa, Kenya; TSI, Toscani in Italia.

However, no LD data are available in the literature for the rs3796508 SNP from the TLR6 gene.

\section{Discussion}

Because TLRs play an active role in the innate immune system, the presence of genotypic alterations may lead to the dysregulation of TLRs at the protein level and could contribute a decrease in the cell innate immunity, leading to the initiation and development of different diseases such as respiratory diseases and cancer..$^{28,29,40}$ To the authors' knowledge, the present study was the first genetic association analysis in Saudi Arabia that targeted the genetic architecture of smokers and its potential association with different smoking-related diseases, particularly asthma and lung cancer. In addition, this is the first study showing that certain SNPs in the TLR2 and TLR6 genes are associated with smoking. It was also demonstrated that the rs5743810 SNP from the TLR6 gene was strongly associated with smokers. This late mutation (Ser249Pro) appears irreversible by the DNA repair system, even in those who smoke only a few cigarettes per day, suggesting that this mutation is highly linked to smoking. This nonsynonymous mutation in the TLR6 exon is generally related to TLR6 expression and consequently may alter the immune function of TLR6. As shown in Figure 1, the regional association LD plot of rs5743810 showed close association with many other SNPs from adjacent genes as well as TLR10 
and TLR1, and this association could enhance the risk of diseases in smokers. Furthermore, this SNP was reported as being involved in endometritis. ${ }^{36}$ However, information about the TLR6 rs5743810 SNP is very limited, especially regarding diseases caused by smoking. As shown in the present study, the rs3796508 SNP in TLR6 did not yield significant results, suggesting that the polymorphism at this particular location is independent of smoking. Regarding the TLR2 rs3804099 SNP, long-term smoking promoted a change in the nucleotide base. From a genotyping point of view, this SNP shows a protective effect (ie, OR $<1$ ), suggesting its potential contribution to the prevention of possible diseases related to smoking, compared to the TLR6 rs5743810 polymorphism. Indeed, TLR2 rs3804099 is correlated with a decreased risk of certain diseases, such as bacterial vaginosis, ${ }^{41}$ whereas TLR6 rs5743810 was associated with an increased risk of Bacillus Calmette-Guérin osteitis. $^{42}$ Interestingly, TLR2 rs3804100 appeared to be

A

rs3804099 (CEU)

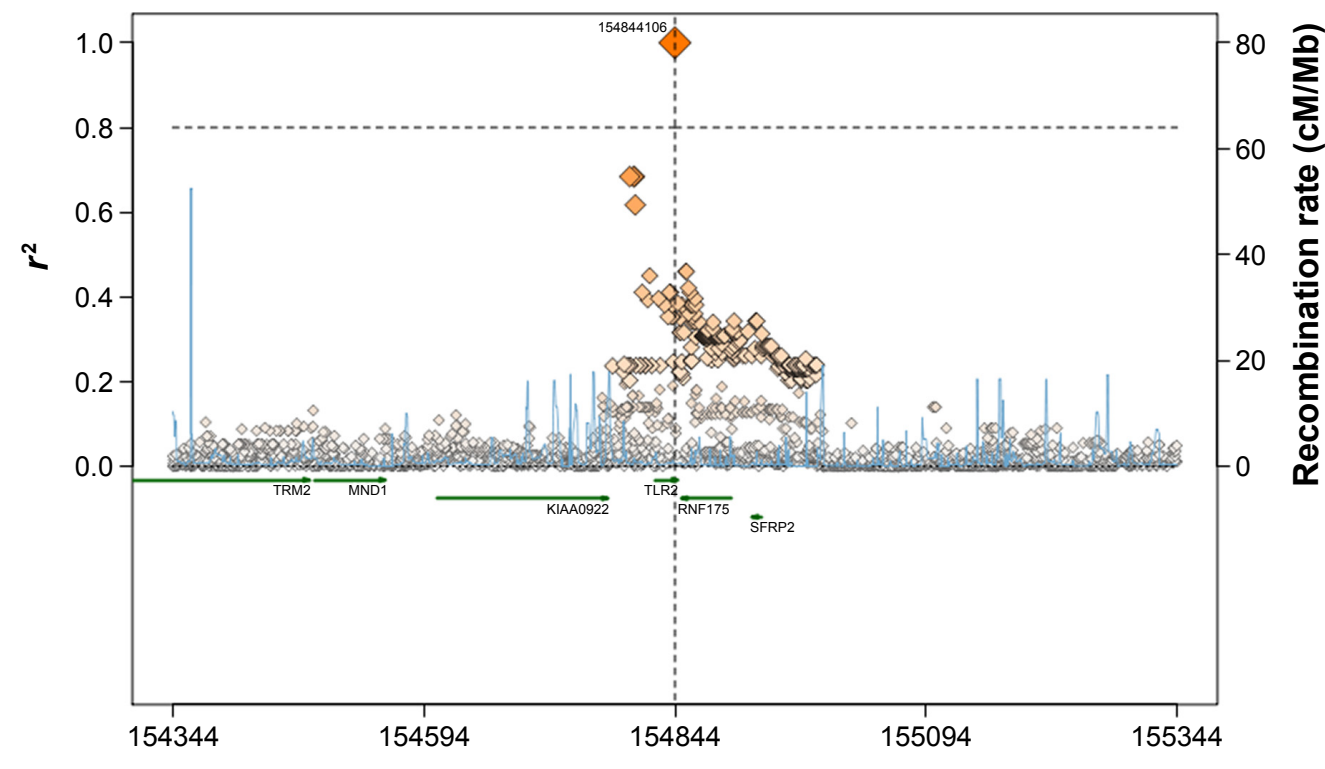

Chromosome 4 position (hg18) (kb)

B

rs3804100 (CEU)

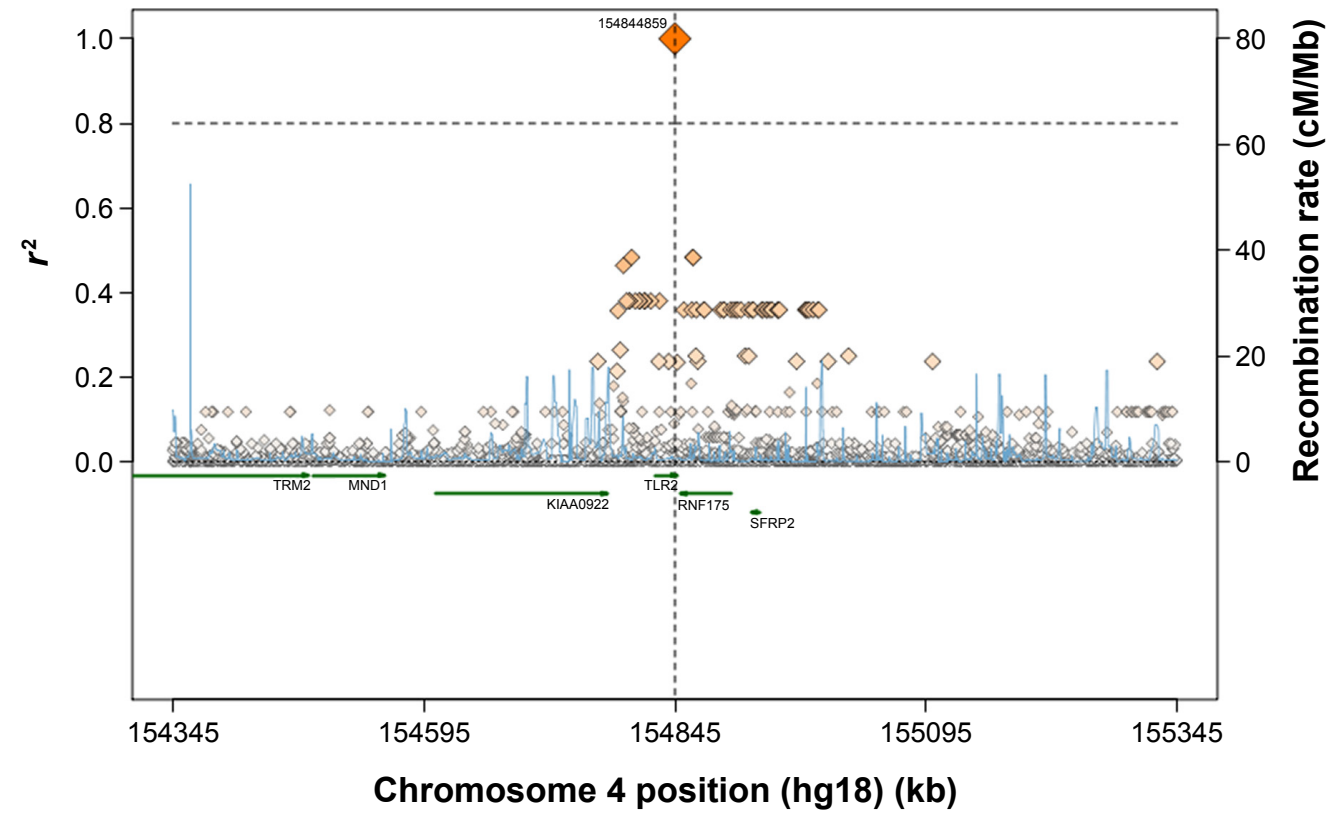

Figure I (Continued) 


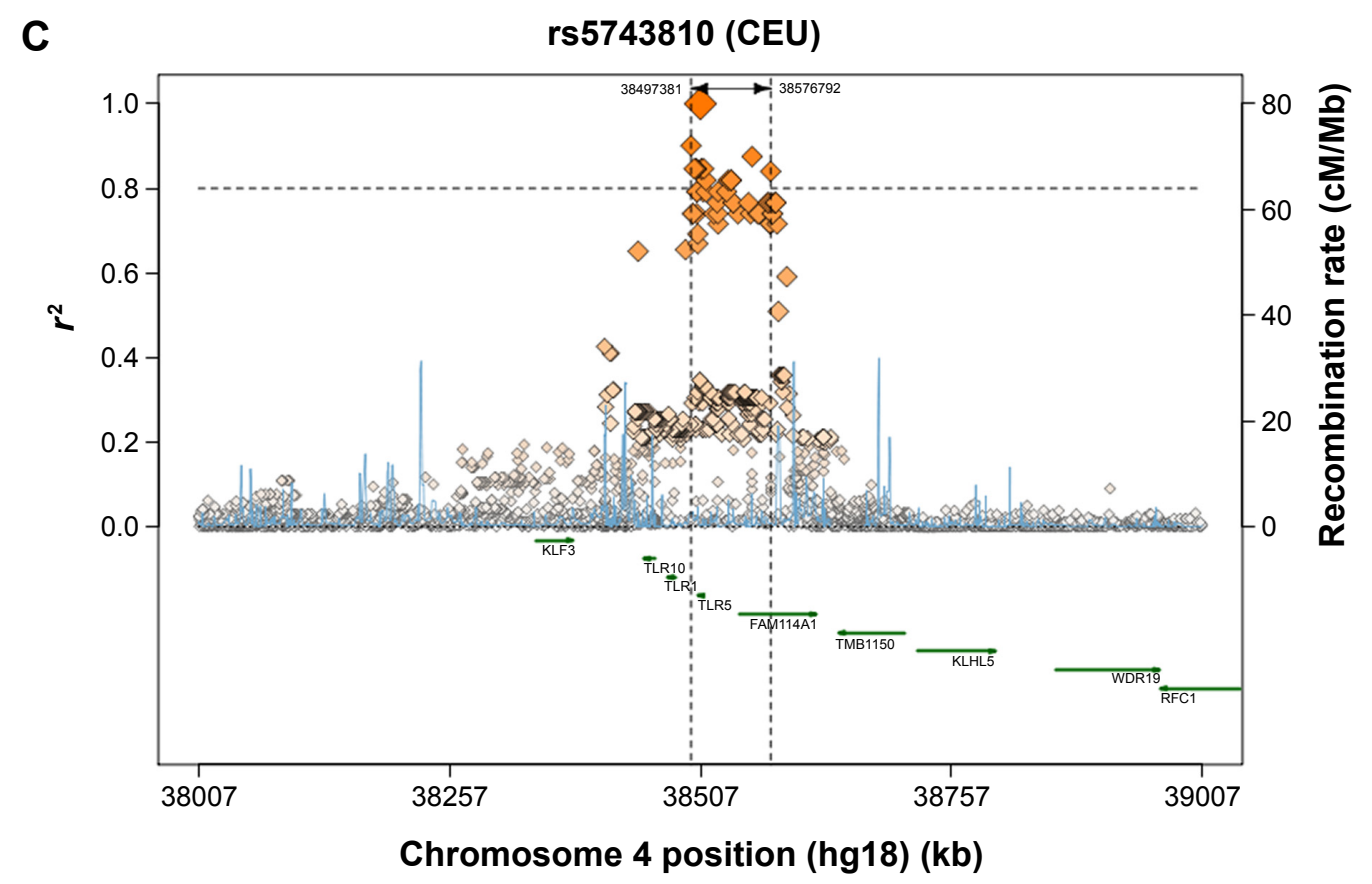

Figure I (A) Regional LD plot for the TLR2 rs3804I00 SNP; (B) regional LD plot for rs3804099 SNP in TLR2; (C) regional LD plot for TLR6 rs57438I0 SNP. Abbreviations: LD, linkage disequilibrium; SNP, single-nucleotide polymorphism; TLR, toll-like receptor; CEU, Caucasian; kb, kilobase; cM, centiMorgan; Mb, megabase.

affected only by short-term smoking, insinuating that the DNA repair processes that make genetic variations to return to their original status may take place only after a certain time. TLR2 rs3804100 and rs3804099 are silent SNPs, which are two genetic variants of the SNP code for the same amino acid. However, these two SNPs were correlated with different diseases. ${ }^{32,33}$ Synonymous SNPs may attenuate the expression of their corresponding genes via their effects on messenger RNA splicing, structure, and stability. In addition, they may affect protein folding by generating pause points during the translation process. Thus, silent SNPs should not be neglected, as described previously. ${ }^{43}$ The imbalance between the protective and detrimental effects of a polymorphism is a key factor in the development of smoking-related diseases at certain points in human lives. The exact mechanism by which lung cancer and asthma may be caused by tobacco is yet to be discovered. Previous studies have demonstrated that smoking leads to innate immune reduction, facilitating different parasite colonization and host infection. ${ }^{44}$ The results of the present study suggested that tobacco smoking may promote different diseases by influencing single-nucleotide variations in TLR genes.

\section{Conclusion}

In summary, this study improved the understanding of the genetic basis of smoking and, consequently, the potential diseases related to smoking. In addition, this study also provided potential targets for future therapeutic intervention.
Further insight into the genetic factors affected by smoking could lead to new approaches for smoking cessation as well as the prevention and treatment of many diseases caused by cigarette smoking. It is important to note that this study has many limitations, including sex-based sample collection due to the social traditions of the country where this study was performed.

\section{Acknowledgment}

This study was supported by funding from the NSTIP Strategic Technologies Program (number 12 MED 2443) in the Kingdom of Saudi Arabia.

\section{Disclosure}

The authors report no conflicts of interest in this work.

\section{References}

1. World Health Organization. WHO Global Report: Mortality Attributable to Tobacco. Geneva: World Health Organization; 2012.

2. World Health Organization. Global Status Report on Non-Communicable Diseases 2010; Description of the Global Burden of NCDs, their Risk Factors and Determinants. Geneva: World Health Organization; 2011.

3. World Health Organization. WHO Report on the Global Tobacco Epidemic, 2008: the MPOWER Package. Geneva: World Health Organization; 2008.

4. Jha P. Avoidable global cancer deaths and total deaths from smoking. Nat Rev Cancer. 2009;9(9):655-664.

5. Bassiony MM. Smoking in Saudi Arabia. Saudi Med J. 2009;30(7): 876-881.

6. El-Zaatari ZM, Chami HA, Zaatari GS. Health effects associated with waterpipe smoking. Tob Control. 2015;24(Suppl 1):i31-i43. 
7. Khanna S. Immunological and biochemical markers in oral carcinogenesis: the public health perspective. Int J Environ Res Public Health. 2008;5(5):418-422.

8. ACS Inc. Cancer Facts \& Figures 2014. Atlanta: ACS Inc.; 2014.

9. Menotti A, Puddu PE, Maiani G, Catasta G. Lifestyle behaviour and lifetime incidence of heart diseases. Int J Cardiol. 2015;201:293-299.

10. Gutierrez A, Suh R, Abtin F, Genshaft S, Brown K. Lung cancer screening. Semin Intervent Radiol. 2013;30(2):114-120.

11. Talaska G, Schamer M, Skipper P, et al. Detection of carcinogen-DNA adducts in exfoliated urothelial cells of cigarette smokers: association with smoking, hemoglobin adducts, and urinary mutagenicity. Cancer Epidemiol Biomarkers Prev. 1991;1(1):61-66.

12. Airoldi L, Orsi F, Magagnotti C, et al. Determinants of 4-aminobiphenylDNA adducts in bladder cancer biopsies. Carcinogenesis. 2002; 23(5):861-866.

13. Vaughan TL, Shapiro JA, Burt RD, et al. Nasopharyngeal cancer in a low-risk population: defining risk factors by histological type. Cancer Epidemiol Biomarkers Prev. 1996;5(8):587-593.

14. Yuan JM, Wang XL, Xiang YB, Gao YT, Ross RK, Yu MC. Nondietary risk factors for nasopharyngeal carcinoma in Shanghai, China. Int J Cancer. 2000;85(3):364-369.

15. Zhu K, Levine RS, Brann EA, Gnepp DR, Baum MK. Cigarette smoking and nasopharyngeal cancer: an analysis of the relationship according to age at starting smoking and age at diagnosis. J Epidemiol. 1997;7(2):107-111.

16. Chao A, Thun MJ, Henley SJ, Jacobs EJ, McCullough ML, Calle EE. Cigarette smoking, use of other tobacco products and stomach cancer mortality in US adults: the Cancer Prevention Study II. Int J Cancer. 2002;101(4):380-389.

17. McLaughlin JK, Hrubec Z, Blot WJ, Fraumeni JF Jr. Stomach cancer and cigarette smoking among U.S. veterans, 1954-1980. Cancer Res. 1990; 50(12):3804.

18. Akiba S, Hirayama T. Cigarette smoking and cancer mortality risk in Japanese men and women - results from reanalysis of the six-prefecture cohort study data. Environ Health Perspect. 1990;87:19-26.

19. Semlali A, Chakir J, Rouabhia M. Effects of whole cigarette smoke on human gingival fibroblast adhesion, growth, and migration. J Toxicol Environ Health A. 2011;74(13):848-862.

20. Alamri A, Semlali A, Jacques E, et al. Long-term exposure of human gingival fibroblasts to cigarette smoke condensate reduces cell growth by modulating Bax, caspase-3 and p53 expression. J Periodontal Res. 2014;50(4):423-433.

21. Semlali A, Chakir J, Goulet JP, Chmielewski W, Rouabhia M. Whole cigarette smoke promotes human gingival epithelial cell apoptosis and inhibits cell repair processes. J Periodontal Res. 2011;46(5): 533-541.

22. Steenaard RV, Ligthart S, Stolk L, et al. Tobacco smoking is associated with methylation of genes related to coronary artery disease. Clin Epigenetics. 2015;7(1):54.

23. Vineis PMN, Lang M, d'Errico A, Caporaso N, Cuzick J, Boffetta P. Metabolic Polymorphisms and Susceptibility to Cancer. Lyon CEDEX, France: IARC Scientific Publications; 1999.

24. Rich AM, Hussaini HM, Parachuru VP, Seymour GJ. Toll-like receptors and cancer, particularly oral squamous cell carcinoma. Front Immunol. 2014;5:464.

25. Sugawara Y, Uehara A, Fujimoto Y, et al. Toll-like receptors, NOD1, and NOD2 in oral epithelial cells. J Dent Res. 2006;85(6):524-529.

26. Oldenburg M, Kruger A, Ferstl R, et al. TLR13 recognizes bacterial 23S rRNA devoid of erythromycin resistance-forming modification. Science. 2012;337(6098):1111-1115.
27. Singh RK, Srivastava A, Singh N. Toll-like receptor signaling: a perspective to develop vaccine against leishmaniasis. Microbiol Res. 2012; 167(8):445-451.

28. Takahashi M, Chen Z, Watanabe K, et al. Toll-like receptor 2 gene polymorphisms associated with aggressive periodontitis in Japanese. Open Dentistry J. 2011;5:190-194.

29. Chan M, Ji SM, Liaw CS, et al. Association of common genetic variants with breast cancer risk and clinicopathological characteristics in a Chinese population. Breast Cancer Res Treat. 2012;136(1):209-220.

30. Turner ML, Cronin JG, Healey GD, Sheldon IM. Epithelial and stromal cells of bovine endometrium have roles in innate immunity and initiate inflammatory responses to bacterial lipopeptides in vitro via Toll-like receptors TLR2, TLR1, and TLR6. Endocrinology. 2014;155(4): 1453-1465.

31. Bjornvold M, Munthe-Kaas MC, Egeland T, et al. A TLR2 polymorphism is associated with type 1 diabetes and allergic asthma. Genes Immun. 2009;10(2):181-187.

32. Zeng HM, Pan KF, Zhang Y, et al. [The correlation between polymorphisms of Toll-like receptor 2 and Toll-like receptor 9 and susceptibility to gastric cancer]. Zhonghua yu fang yi xue za zhi. 2011;45(7): 588-592. Chinese.

33. Wu L, Hu Y, Li D, Jiang W, Xu B. Screening toll-like receptor markers to predict latent tuberculosis infection and subsequent tuberculosis disease in a Chinese population. BMC Med Genet. 2015;16:19.

34. Noreen M, Arshad M. Association of TLR1, TLR2, TLR4, TLR6, and TIRAP polymorphisms with disease susceptibility. Immunol Res. 2015; 62(2):234-252.

35. Cotterchio M, Lowcock E, Bider-Canfield Z, et al. Association between variants in atopy-related immunologic candidate genes and pancreatic cancer risk. PLoS One. 2015;10(5):e0125273.

36. Taylor BD, Darville T, Ferrell RE, Ness RB, Haggerty CL. Racial variation in toll-like receptor variants among women with pelvic inflammatory disease. J Infect Dis. 2013;207(6):940-946.

37. Yang H, Zhang X, Geng J, Zheng Z, Fu Q. Toll-like receptor 6 V327M polymorphism is associated with an increased risk of Klebsiella pneumoniae infection. Pediatr Infect Dis J. 2014;33(11):e310-e315.

38. Alanazi M, Pathan AA, Abduljaleel Z, et al. Association between PARP-1 V762A polymorphism and breast cancer susceptibility in Saudi population. PLoS One. 2013;8(12):e85541.

39. The International HapMap Project. Nature. 2003;426(6968):789-796.

40. Kutikhin AG. Association of polymorphisms in TLR genes and in genes of the Toll-like receptor signaling pathway with cancer risk. Hum Immunol. 2011;72(11):1095-1116.

41. Mackelprang RD, Scoville CW, Cohen CR, et al. Toll-like receptor gene variants and bacterial vaginosis among HIV-1 infected and uninfected African women. Genes Immun. 2015;16(5):362-365.

42. Poyhonen L, Nuolivirta K, Vuononvirta J, et al. Toll-like receptor 2 subfamily gene polymorphisms are associated with Bacillus CalmetteGuerin osteitis following newborn vaccination. Acta Paediatr. 2015 104(5):485-490.

43. Hunt R, Sauna ZE, Ambudkar SV, Gottesman MM, Kimchi-Sarfaty C. Silent (synonymous) SNPs: should we care about them? Methods Mol Biol. 2009;578:23-39.

44. Ortega E, Barriga C, Rodriguez AB. Decline in the phagocytic function of alveolar macrophages from mice exposed to cigarette smoke. Comp Immunol Microbiol Infect Dis. 1994;17(1):77-84. 


\section{Supplementary material}

Table SI Description of the selected SNPs

\begin{tabular}{llllll}
\hline Gene & SNP ID & SNP location & SNP type & Amino acid/nucleotide change & Ancestral allele \\
\hline TLR2 & rs3804I00 & NC_000004.II:g.154625409 & Exon & Ser450Ser & T $>$ C \\
& rs3804099 & NC_000004.II:g.154624656 & Exon & Asn199Asn & C $>$ T \\
TLR6 & rs3796508 & NC_000004.II:g.38830II6 & Exon & Val327Met & G $>$ A \\
& rs57438I0 & NC_000004.II:g.38830350 & Exon & Ser249Pro & C $>$ T \\
\hline
\end{tabular}

Abbreviations: SNP, single-nucleotide polymorphism; TLR, toll-like receptor.

\section{Publish your work in this journal}

OncoTargets and Therapy is an international, peer-reviewed, open access journal focusing on the pathological basis of all cancers, potential targets for therapy and treatment protocols employed to improve the management of cancer patients. The journal also focuses on the impact of management programs and new therapeutic agents and protocols on

patient perspectives such as quality of life, adherence and satisfaction. The manuscript management system is completely online and includes a very quick and fair peer-review system, which is all easy to use. Visit http://www.dovepress.com/testimonials.php to read real quotes from published authors. 